\title{
The Effect of Auditor Ethics, Auditor Experience, Audit Fees, and Auditor's Motivation on Audit Quality
}

(Case study of a Public Accounting Firm in Semarang)

\author{
Mulyani, Ika \\ Politeknik Negeri Semarang, Semarang \\ $\triangle$ sekretariat[at]polines.ac.id
}

\begin{abstract}
The purpose of this paper is to identify the effect of Auditor Ethics, Auditor Experience, Audit Fees, and Auditor's Motivation on Audit Quality.

The population of this research is the Auditor at the Public Accountant Office in Semarang. The sampling technique uses Simple Random Sampling. The data used in this study are primary data taken by distributing questionnaires. The analysis model uses multiple linear regression analysis models, while the analysis technique uses the Statistical Test $\mathrm{F}$, the Coefficient of Determination $\left(R^{2)}\right.$, and the Statistical test $t$.

The results of the analysis and discussion showed that the auditor's ethical variables, auditor's experience, audit fees, and auditor's motivation simultaneously had a significant effect on audit quality. Auditor ethics, auditor experience, and Auditor Motivation on the quality of each audit partially significant effect on audit quality. Whereas Audit Fee partially has no significant effect on Audit Quality.
\end{abstract}

Keywords : Audit Quality, Auditor Ethics, Auditor Experience, Audit Fees, and Auditor's Motivation

\section{INTRODUCTION}

The amount of trust of users of financial statements in the Public Accountant requires public accountants to pay attention to the quality of the audit. Therefore auditors must produce quality audits so as to reduce disharmony that occurs between the management and the owner. Many cases of companies that "fail" business failures are associated with auditor failures, this threatens the credibility of financial statements. This threat further affects public perceptions, especially users of financial reports on audit quality (Hanjani, 2014). De Angelo (1981) defines audit quality as the probability that the auditor will find and report violations in the client's accounting system. Whether or not the quality of the work of the auditor will affect the auditor's final conclusions and indirectly will affect whether or not the decision will be taken by parties outside the company. So that auditors are required to feel a sense of responsibility (accountability) in each carrying out their work and have a professional attitude.

Considering the role of auditors is needed by the business community, the auditor has an obligation to maintain the standards of their ethical behavior towards the organization where they work, their profession, society and themselves (Anni, 
2004). In general, ethics is a moral principle and acts which are the basis of one's actions so that what they do is seen by the community as commendable and increases one's dignity and honor including in improving audit quality (Munawir, 2007). Every auditor is expected to uphold the professional ethics set by the Indonesian Institute of Accountants (IAI), so that the situation of unfair competition can be avoided. Accountant ethics becomes a very interesting issue. This is in line with the occurrence of several ethical violations committed by accountants both independent accountants, internal corporate accountants and government accountants (Dewi, 2009). Suraida (2005) research results, empirically proved that ethical factors have a positive effect on audit quality. While research results from Triana (2017) auditor ethics have no effect on audit quality.

In addition to the professional ethics that must be possessed, the auditor must also act as an expert in the fields of accounting and auditing. Achievement of expertise begins with formal education, which is then through experience and practice auditing (SPAP, 2001). Rahmawati and Winarna (2002) in their research found the fact that auditors, expectation gaps occur due to lack of experience and knowledge which is only limited to college. Audit experience is demonstrated by flying hours in conducting audit procedures related to giving opinions on audit reports. According to Libby and Frederick (1990) the experience of the auditor will affect the quality of the audit, they find that the more experience the auditor can produce various allegations in explaining audit findings. For various reasons as stated above, work experience has been seen as an important factor in predicting the performance of public accountants, in this case the quality of the audit. Research conducted by Nirmala and Cahyonowati (2013) shows that independence, work experience and accountability have a significant positive effect on audit quality. In contrast to research conducted by Samsi, et al (2013) which shows that work experience negatively affects the quality of examination results.

According to Wanous, et al (1983), one factor for an auditor to carry out his work is audit fees. Jusup (2001: 104) states that the amount of audit fees can vary depending on the risk of assignment, the complexity of the services provided, the level of expertise required to perform these services, the KAP fee structure concerned and other professional considerations. The complexity of the service referred to is the complexity of the company regarding the number of subsidiaries and the number of employees. The more complex the client, the more difficult it is to audit and requires more time so that the audit fee is higher (Hay et al., 2006). Research by Prasitha and Widhiyani (2014) results that audit fees significantly affect audit quality. However, based on Ramdani's research (2016) audit fees have no significant effect on audit quality.

In addition to the factors above, motivation is an impetus that arises from within humans to take an action. Although there are human activities carried out without motivation, but almost all behaviors that are carried out consciously have motivation or cause. Needs give rise to potentials that are modified by one's environment and give rise to certain desires. Upon one's consideration of the situation as a whole, that person will be motivated to take action (Aditya A, 2013). According to Mills (1993: 30), the motivation of auditors in carrying out audits is basically to continue and business continuity that benefits him. Motivation also arises because it believes that the auditor can carry out the audit, besides due to customer 
demand and commercial needs. Audit quality will be high if the wants and needs of auditors make their work motivation fulfilled. Sinambela research (2109) shows that motivation has a significant effect on audit quality. While the results of research from Fauziah (2107) motivation does not significantly influence audit quality.

\section{THEORY AND METHODE}

\subsection{Agency Theory}

\section{Audit Quality}

According to De Angelo (1981) audit quality is a problem found by auditors in the client's accounting system and reporting violations. According to Halim (2015: 61) financial statements that are useful for making; quality financial statement decisions (approval of relevance and reliability criteria). The users of financial statements are more confident about the quality of the company's financial statements audited financial statements that have been audited and meet both criteria. From the standpoint of the public accounting profession, an audit is an objective examination of the financial statements of a company or other organization with the aim of determining whether the financial statements present fairly, in all material respects, the financial position and the results of operations of a company or organization these (Mulyadi, 2002: 11).

\section{Auditor Ethics}

Ethics deals with the question of how people will behave towards each other (Kell et al., 2002 in Alim, et al 2007). Meanwhile, according to Maryani and Ludigdo (2001) defines ethics as a set of rules or guidelines governing human behavior both to be done and to be abandoned that is adhered to by a group or group of people or society or profession. According to Lubis (2009), auditors must comply with the established Code of Ethics. The audit must refer to the Audit Standards and the Code of Ethics which are an inseparable part of the audit standard.

\section{Auditor's Experience}

An auditor must continuously follow the developments that occur in the business and profession. With the increasing experience of an auditor, the auditor's expertise is also growing. This indicates that the longer the work period and the more experience the auditor has, the better the quality of the audits produced (Badjuri, 2011). Someone's work experience shows the types of work someone has done and provides a great opportunity for someone to do a better job. The more extensive one's work experience, the more skilled a person is at doing work and the more perfect the pattern of thinking and attitude in acting to achieve the stated goals (Abriyani Puspaningsih, 2004).

\section{Audit Fee}

According to Mulyadi (2002) audit fees are fees received by public accountants after carrying out their audit services, the magnitude of which depends on the risk of the assignment, the complexity of the services provided, the level of expertise required to carry out the services, the KAP fee structure concerned. Audit fees can also be interpreted as a function of the amount of work done by the auditor and the price per hour (Al-Shammari et al., 2008). According to Wanous, et al (1983) audit fee is one of the factors of an auditor to carry out his work. According to Haryono Jusup (2001: 
104), the amount of audit fees can vary depending on the assignment risk, the complexity of the services provided, the level of expertise required to perform the service, the relevant KAP fee structure and other professional considerations. The more complex the client, the more difficult it is to audit and requires more time so that the audit fee is higher (Hay et al., 2006)

\section{Auditor Motivation}

Motivation is a process that explains the intensity, direction and perseverance of an effort to achieve a goal (Robbins and Judge 2008). Motivation is the result of interaction between individuals and situations. The main elements of motivation are intensity, direction and perseverance. According to Robbins and Judge (2008), intensity is related to how actively someone tries. However, high intensity will not produce a satisfying achievement unless it is associated with a favorable direction. Motivation has the dimension of perseverance, which is a measure of how long a person can keep his business. Motivation in a person encourages individual desires to carry out certain activities to achieve goals (Reksohadiprodjo, 1990). Audit quality will be high if the wants and needs of auditors make their work motivation fulfilled. Compensation from organizations in the form of rewards according to their profession, will lead to audit quality because they feel that the organization has paid attention to the needs and expectations of their work.

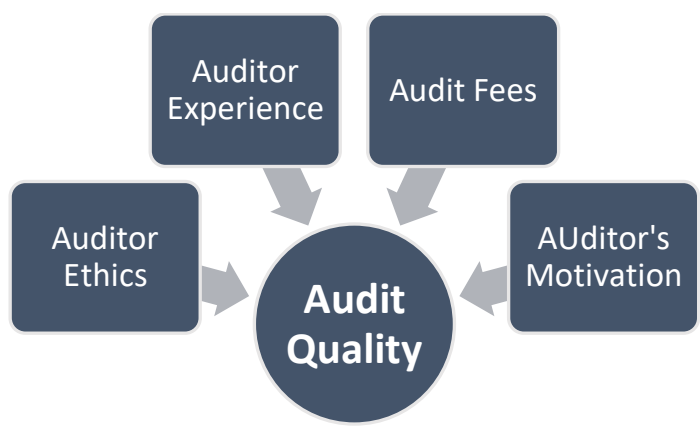

Picture 1: Research Model

\subsection{Research Methods}

The type of data used in this study is primary data collected through sending questionnaires to respondents. Sources of data in this study were obtained from auditors at the Public Accounting Firm (KAP) Semarang. The model used is multiple linear regression with the analysis techniques $\mathrm{F}$ test, $\mathrm{R} 2$ and $\mathrm{t}$ test.

\section{RESULT AND DISCUSSION}

\subsection{Analiys Data}

\section{F Test}

Based on the F test produced the Annova Table in Table 1.

Table 1. Result F Test

ANOVA ${ }^{\mathrm{a}}$ 


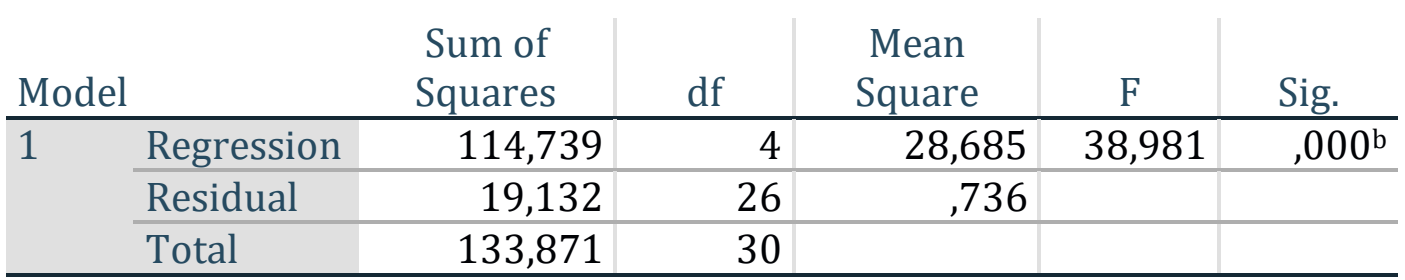

a. Dependent Variable: Kualitas

b. Predictors: (Constant), Motvasi, Pengalaman, Fee, Etika

Source: Data processed, 2019.

$R^{2}$ Test.

Based on the $\boldsymbol{R}^{2}$ test produced the Annova Table in Table 2.

Table 2. Result $R^{2}$ Test

Model Summary

\begin{tabular}{ll|r|r|r} 
Model & $\mathrm{R}$ & R Square & $\begin{array}{c}\text { Adjusted R } \\
\text { Square }\end{array}$ & $\begin{array}{l}\text { Std. Error of } \\
\text { the Estimate }\end{array}$ \\
\hline 1 &, $926^{\mathrm{a}}$ &, 857 &, 835 &, 85782 \\
\hline
\end{tabular}

a. Predictors: (Constant), Motvasi, Pengalaman, Fee, Etika

Source: Data processed, 2019.

t Test

Based on the $t$ test produced the Annova Table in Table 3

Table 3. Result t Test

\section{Coefficients $^{a}$}

\begin{tabular}{|c|c|c|c|c|c|c|}
\hline \multirow{2}{*}{\multicolumn{2}{|c|}{ Model }} & \multicolumn{2}{|c|}{$\begin{array}{l}\text { Unstandardized } \\
\text { Coefficients }\end{array}$} & \multirow{2}{*}{$\begin{array}{c}\text { Standardize } \\
\mathrm{d} \\
\text { Coefficients } \\
\text { Beta } \\
\end{array}$} & \multirow[b]{2}{*}{$\mathrm{T}$} & \multirow[b]{2}{*}{ Sig. } \\
\hline & & $\mathrm{B}$ & Std. Error & & & \\
\hline \multirow[t]{5}{*}{1} & (Constant) &,- 524 & 1,591 & &,- 329 &, 744 \\
\hline & Etika &,- 125 &, 059 &,- 217 & $-2,130$ & ,043 \\
\hline & Pengalaman & ,826 & ,089 & ,903 & 9,317 & ,000 \\
\hline & Fee &,- 044 & ,056 &,- 075 &,- 787 & ,438 \\
\hline & Motvasi & ,158 & , 057 & ,281 & 2,767 & , 010 \\
\hline
\end{tabular}

a. Dependent Variable: Kualitas

Source: Data processed, 2019.

\subsection{Pembahasan}

a. Effect of Auditor Ethics, Auditor Experience, Audit Costs, and Auditor Motivation on Audit Quality

Based on ANOVA table, Fcount 38,981> Ftable 3,178 or significance 0,000 $<0,05$, which means Auditor Ethics, Auditor Experience, Audit fees, and Auditor Motivation simultaneously. significant effect on Audit Quality. Thus the hypothesis stating the alleged Auditor Ethics, Auditor Experience, Audit fees, and Auditor Motivation simultaneously. significant effect on the Quality of Audit declared received.

Based on the Summary Model Table, the adjusted R Square value of 0.835 means that the Auditor Ethics, Auditor Experience, Audit fees, and Auditor 
Motivation contribute to Audit Quality by $83.5 \%$. While the remaining $16.5 \%$ is influenced by other factors not included in the study (not included in the model.)

\section{b. Effect of Auditor Ethics on Audit Quality}

Based on the Coefficients Table, the tcount of ethics is 2.130>2.0301 ttable or the significance is $0.043<0.05$ which means that the Auditor Ethics partially has a significant effect on Audit Quality. Thus the hypothesis stating that the alleged Auditor Ethics partially had a significant effect on Audit Quality was accepted.

c. Effect of Auditor Experience on Audit Quality

Based on the Table of Coefficients generated tcount experience 9.317> 2.0301 ttable or a significance of $0.000<0.05$ which means the Auditor's Experience partially has a significant effect on Audit Quality. Thus the hypothesis stating that the alleged Auditor Experience partially had a significant effect on Audit Quality was accepted.

d. Effect of Audit Fee on Audit Quality.

Based on the Coefficients Table, it is produced that the Audit Fee is 0.787 $<2.0301$ ttable or the significance is $0.438<0.05$ which means that the Audit Fee partially has a significant effect on Audit Quality. Thus the hypothesis that allegedly charged Audit Fee partially has a significant effect on Audit Quality is stated in the reject.

e. Effect of Auditor Motivation on Audit Quality

Based on the Coefficients Table, the tcount of Auditor Motivation is 2.767> 2.0301 ttable or $0.010<0.05$ which means that Auditor Motivation partially has a significant effect on Audit Quality. Thus the hypothesis which states that allegedly the Auditor's Motivation partially has a significant effect on Audit Quality is declared acceptable.

\section{Conclution}

The results of the analysis and discussion showed that the auditor's ethical variables, auditor's experience, audit fees, and auditor's motivation simultaneously had a significant effect on audit quality. Auditor ethics, auditor experience, and Auditor Motivation on the quality of each audit partially significant effect on audit quality. Whereas Audit Fee partially has no significant effect on Audit Quality. 


\section{REFERENCE}

Aini, Nur.2009. Pengaruh Kompetensi, Independen, Dan Motivasi Terhadap Kualitas Audit Dalam Pengawasan Keuangan Daerah. Skripsi: UIN Syarif Hidayatullah.

Andriani dan Nursiam. 2017. Pengaruh Fee Audit, Audit Tenure, Rotasi Audit Dan Reputasi Auditor Terhadap Kualitas Audit. Riset Akuntansi dan Keuangan Indonesia Vol. 3, No. 1.

Cahyani, Gusti \& Zulvia, Dewi. 2019. Pengaruh Etika Audit Dan Fee Audit Terhadap Kualitas Audit Di Kantor Akuntan Publik (Kap) Kota Padang. Jurnal Pundi Vol. 03, No. 01. Maret.

Fatika. 2018. Pengaruh Akuntabilitas, Pengalaman Kerja, Independensi Auditor Dan Etika Auditor Terhadap Kualitas Audit. Skripsi: Universitas Muhammadiyyah Surakarta.

Fauziah. 2017. Pengaruh Kompetensi, Independen, Dan Motivasi Terhadap Kualitas Audit Dalam Pengawasan Keuangan Daerah. Riset dan Jurnal Akuntansi. Vol. 1, No. 1.

Haeridistia, Nurlita \& Fadjarenie, Agustin. 2019. The Effect Of Independence, Professional Ethics And Auditor Experience On Audit Quality. International Journal of Scientific \& Technology Research Vol. 8, Issue 02.

Hanifah. 2018. Analisis Pengaruh Kompetensi dan Etika Auditor terhadap Kualitas Audit. Skripsi: Universitas Pasundan Bandung

Hanjani, Andreani. 2014.Pengaruh Etika Auditor, Pengalaman Auditor, Fee Audit, Dan Motivasi Auditor Terhadap Kualitas Audit. Diponegoro Journal Of Accounting Vol. 3, No. 2, Hal 1-9.

Kovinna \& Betri. 2014. Pengaruh Independensi, Pengalaman Kerja, Kompetensi, Dan Etika Auditor Terhadap Kualitas Audit. Jurnal: STIE MDP.

Kuntari et al. 2017. The Effect of Auditor Ethics, Auditor Experience, Audit Fees and Auditor Motivation on Audit Qualit. Sriwijaya International Journal Of Dynamic Economiccs And Business Vol. 1(2) Hal 203-218.

Lestari, Desi Wahyu. 2017. Pengaruh Fee Audit, Independensi, Kompetensi, Etika Auditor Dan Tekanan Anggaran Waktu Terhadap Kualitas Audit. Skripsi: IAIN Surakarta.

Prakasa, Chesar. 2017. Pengaruh Independensi, Integritas, Dan Pengalaman Auditor Terhadap Kualitas Audit. Skripsi. Universitas Negeri Yogyakarta.

Radianti, Serli. 2017. Analisis Pengaruh Tenure Audit, Fee Audit Dan Spesialisasi Auditor Terhadap Kualitas Audit. Skripsi: Universitas Lampung.

Ramdani, Rifki. 2016. Pengaruh Fee Audit, Audit Tenure, Rotasi Audit Dan Ukuran Perusahaan Klien Terhadap Kualitas Audit. Skirpsi: IAIN Surakarta. 
Setiyawan, Andi. 2018. Analisis Pengaruh Etika Auditor, pengalaman auditor, Fee Auditor, Motivasi Auditor Terhadap Kualitas Audit. Skripsi: Universitas Muhammadiyah Surakarta.

Sinambela, Tongan. 2019. Pengaruh Kompetensi, Independensi, Dan Motivasi Terhadap Kualitas Audi. Jurnal Bisnis dan Akuntansi Unsurnya Vol. 4, No. 1 Januari.

Suyanti, dkk. Pengaruh Profesionalisme, Pengalaman, Akuntabilitas dan Objektivitas Auditor Terhadap Kualitas Audit. Ejournal.ukanjuruhan.ac.id

Triana, Anggi Cahyaning. 2017. Pengaruh Independensi, Etika Auditor, Kompetensi, Dan Standar Audit Terhadap Kualitas Audit. Skripsi: Universitas Muhammadiyyah Surakarta. 